\title{
The Idea of South Asia and the Role of the Middle Class ${ }^{\dagger}$
}

\author{
Nirvikar Singh \\ University of California, Santa Cruz
}

March 7, 2006

\begin{abstract}
In the post-colonial world, the countries of South Asia have evolved politically in different ways, amidst internal and regional conflicts, but retained some commonality of institutions and cultures. Since the 1990s, the promise of market-led development and the growth of a middle class, especially in India, have reshaped expectations in a way not seen since the immediate post-colonial period, and provided the prospect of a region that combines its particular approach to governance with common aspirations and achievement of economic well-being - what might be a new "idea of South Asia." This paper examines some aspects of the development of the South Asian middle class, their role in economic development, and the potential of the idea that shared middle class aspirations of material consumption can be a regional driving force. The paper argues that, for this potential to be realized, the middle class in South Asia may need to aspire to something more than private affluence in the midst of public squalor. In that case, a new idea of South Asia will require building social capital in ways that will challenge all of the region's societies. Effective collective action across, but first within, the nations of South Asia will be the true test of whether this potential South Asian identity emerges.
\end{abstract}

Keywords: Middle class, public goods, identity, heterogeneity

JEL codes: O57, P46

\footnotetext{
${ }^{\dagger}$ This is a substantially revised version of a paper prepared for a conference marking the launch of the Institute for South Asian Studies at the National University of Singapore, January 27-28, 2005. I am grateful to the organizers for inviting me to participate, and to Anthony D'Costa for helpful comments at the conference. I am particularly indebted to Inderjit N. Kaur for extremely helpful discussions on the ideas developed in this paper. A version of the paper was also presented at the National Institute of Public Finance and Policy, New Delhi, and on that occasion I received very helpful comments from seminar participants, especially Amaresh Bagchi, Surjit Bhalla, M. Govinda Rao and D.K. Srivastava. Finally, I am also grateful to Devesh Kapur, Nicholas Hope and Charan Singh for helpful suggestions on an earlier draft. I alone am responsible for all remaining errors and omissions.
} 


\title{
The Idea of South Asia and the Role of the Middle Class
}

\author{
Nirvikar Singh \\ University of California, Santa Cruz
}

\section{Introduction}

The term "South Asia" is now applied to what, in colonial days, was commonly known as the "Indian subcontinent" - a diverse mix of British India and a range of kingdoms with varying degrees of subservience and fealty to the colonial power. In some respects, the British followed earlier models of decentralized governance for this populous and heterogeneous region, incorporating institutional structures that dated to Mughal days or earlier. At the same time, they added Anglo-Saxon institutions of administration, politics and law, creating superstructures that were novel for that part of the world. These superstructures have been assimilated and preserved to varying degrees in different parts of South Asia, but, nevertheless, have maintained some commonality across the independent political units that emerged from 1947 onwards.

Of course, there are older commonalities, beyond the simple facts of geography, which define the region as a recognizable entity: language, religion, culture and learning all contribute dimensions of South Asian identity. If one goes far enough back in history, all of these dimensions evolved and flourished in South Asia, being exported well beyond the region: language scripts, the concept of zero, Buddhism, Hinduism, dance and music went from South Asia to all points of the compass. At the same time, the land continually absorbed ideas and peoples from other places, especially from the North and West. What we now think of as quintessentially "South Asian" is often an eclectic mix of such interactions.

Colonial-era governance institutions also provided a South Asian framework for the much broader project of economic development, which began with the unwinding of imperialism. The independence of India, Pakistan and Sri Lanka (then Ceylon) in 194748 marked, in fact, a major step down this road, traversed in very different ways by many other ex-colonies. Each South Asian country has pursued a somewhat different development strategy, and in each case, the results have been mixed, punctuated by sometimes severe political conflicts. In contrast, many of the countries of South East and East Asia, whether former colonies or not, began to pull away in the 1960s in terms of economic performance, and became a new example for South Asia to consider, and possibly to follow.

In India, in particular, the 1990s saw a significant shift in economic policy, away from state-led, and towards market-led development - if one is permitted to simplify and encapsulate a complex and ongoing process. Faster economic growth has seen the 
expansion of the middle class, ${ }^{1}$ and, even more significantly, has reshaped their expectations of material progress in a way not seen since the optimism of the immediate post-colonial period. In fact, the recent downplaying of Gandhian ideals of austerity represents a break with a central piece of India's $20^{\text {th }}$ century political discourse. Aspirations for consumption of personal care products, electronics, motor vehicles, resort vacations, and house furnishings have changed dramatically in the last decade, as have their availability and relative affordability for India's middle classes. The marketing of such items has become more pervasive and sophisticated, particularly supported by the growth of satellite and cable television. Television and Indian movies have carried these new perceptions to the rest of South Asia, spreading over the region's heterogeneous political and social systems, cultures and phases of development. This common consumption of images, and of products and services, creates a new "idea of South Asia."

Will this idea of South Asia, based on shared aspirations and realities of material consumption and progress, replace or transcend traditional cultures, religious attitudes, languages and social norms? At some level, this is the vision of those who are opponents, as well as those who are proponents, of globalization in its current form - the two sides may differ more in their normative values than in their positive predictions. This paper suggests that there is something more to be considered in the co-evolution of South Asia's economies and societies. We examine the potential of the idea that shared middle class aspirations of material consumption can be a regional driving force. We argue that, for this potential to be realized, the middle class in South Asia may need to aspire to something more than private affluence in the midst of public squalor. A truly new idea of South Asia will require building social capital - using that term broadly to include physical, organizational and societal infrastructure - in ways that will challenge all of the region's societies. Effective collective action within and across ${ }^{2}$ the nations of South Asia will be the true test of whether this potential identity emerges fully. Without more inclusiveness in the process of growth within each South Asian nation, the idea and the growth of South Asia will both remain stunted.

The remainder of this paper is organized as follows. Section 2 briefly discusses "South Asia” as a term for an idea as well as a geographic region. Section 3 surveys some basic facts concerning the economies of the major South Asian nations, including consumption patterns, demographics, and changes in measures of economic well-being. Section 4 examines the concept of the middle class more systematically, including its definition and its role in economic growth, as well as some of the qualitative aspects of social change, with respect to the perception of what it means to be middle class. Section 5 examines inequality, both economic and social, and draws out the economic implications of a situation where only a fraction of the population has capabilities that enable full participation in the market economy. In particular, attitudes towards, and institutions for, the provision of public goods are discussed. Section 6 considers economic and social

\footnotetext{
${ }^{1}$ For an early-post-liberalization analysis of this change, see Rao and Natarajan $(1994,1996)$.

${ }^{2}$ Clearly, explicit regional cooperation as embodied in institutions such as the South Asian Association for Regional Cooperation (SAARC). On the economic front, intraregional trade is one obvious starting point for cooperation, but discussion of trade policy is outside the scope of this paper, which instead suggests that developments at the national level must come first.
} 
policy responses that may have positive consequences for broad-based economic growth, as well as for more comprehensive measures of development. Section 7 concludes with an assessment of the "idea of South Asia" as a region that may come to combine its particular approach to governance with common aspirations and achievement of economic well-being.

\section{The Concept of South Asia}

It is important to provide some background discussion of the meaning of the term "South Asia," because it will frame the subsequent analysis. The most basic conceptualization of "South Asia" is as a geographic region, with the underlying motivation being geopolitics. One can, for example, correlate the use of the term with the need for an academic label for departments of study and for region-focused research centers, which - in the United States in particular - have relied on government funding tied to perceptions of strategic importance. The relative neutrality of the term has given it preference over the colonialera "Indian subcontinent." In practical terms, one has to specify precisely which nationstates are encompassed within this label, and the South Asian Association for Regional Cooperation (SAARC), as the only significant region-level organization, provides one current operational boundary, including seven countries: Bangladesh, Bhutan, India, Maldives, Nepal, Pakistan, and Sri Lanka. One can argue that SAARC should not define South Asia, excluding and perhaps thereby marginalizing Afghanistan and Myanmar (Burma), but we do not propose to tackle such issues here.

In fact, for many purposes, the five largest of the SAARC countries (in order of population size, India, Pakistan, Bangladesh, Sri Lanka and Nepal) are the ones that matter. In particular, the colonial legacy of governance institutions (legislative, bureaucratic and judicial) and social norms (kinship and status) applies particularly to the four largest South Asian nations. Ultimately, it is this British imperial heritage, overlaid on culture and history, which in many ways defines a core concept of South Asia. As we shall illustrate in the next section, the economic progress of these countries has been quite similar, and this is arguably the result of similar institutional characteristics and social norms, which transcend national boundaries within the region, but, at the same time, distinguish the region from other ex-British colonies.

Governance and social institutions obviously have impacts for how collective action is achieved, and therefore how levels of public goods and services are decided and delivered. Furthermore, norms deriving from culture and tradition have implications for consumption patterns of private goods, including food, clothing, and entertainment. These patterns not only shape or reinforce self-identities, but also identities as perceived by outsiders. ${ }^{3}$ Two implications follow from these broad observations. First, there is a regional identity, defined and shaped significantly by economic and social factors, which

\footnotetext{
${ }^{3}$ Lal (2003) puts this very picturesquely, though obviously with some resulting simplification and distortion, "a South Asian identity has become a reality in most other parts of the world. Whether one is dismissed as a 'Paki' or ridiculed as Indian, people from all over South Asia have come to be identified with curry, qawaali, cricket, Hindi films, and a distinct variety of imperial English.”
} 
transcends national boundaries within the region. Second, this identity is largely circumscribed by this region, extending outside only through migration, and only partially in that case. ${ }^{4}$ Together, these two implications help to justify the scope of our analysis, in focusing on a South Asian middle class and its role in regional economic development.

Interestingly, the shared goals of economic progress and human development are at the core of the stated aims of SAARC. The principal goal of SAARC is "to promote the welfare of the peoples of South Asia, to improve their quality of life, to accelerate economic growth, social progress and cultural development and to provide all individuals the opportunity to live in dignity and to realize their full potential."5 This statement goes much deeper than objectives such as strategic cooperation or regional trade agreements, and represents an embodiment of the potential idea of South Asia that is developed in this paper.

\section{South Asian Economic Development}

To set the stage for a discussion of the current and potential role of the middle class, we first provide a summary of various economic and social indicators for the five largest South Asian countries: India, Pakistan, Bangladesh, Sri Lanka and Nepal. The data are all taken from the World Bank World Development Indicators database, and are reported in Table 1. While Sri Lanka and Nepal are outliers at either end, the three largest countries display many similarities in terms of their economic situations, including income levels, economy structures, and human development indicators. These similarities, as well as the differences (in areas such as birthrates and female literacy), are well-known, and have been discussed and analyzed extensively. ${ }^{6}$

Looking specifically at demographics, Table 2 provides data on age composition and dependency ratios. Currently, Sri Lanka has the most favorable dependency ratio, while Pakistan has the worst. However, over the next 15 years, as the proportion of old dependents in Sri Lanka increases, India's dependency ratio will become the lowest of the five South Asian countries. If Pakistan undergoes a demographic transition, in which its birth rate and population growth rate begin to decline substantially, its dependency ratio will improve over the same period, but remain relatively high. ${ }^{7}$ In any case, the demographics of South Asia indicate a period of growing working age populations, which will pose challenges for education and for employment. If these challenges are

\footnotetext{
${ }^{4}$ Thus, emigrants from the region retain some social norms and consumption patterns, but operate in different political, economic and social environments. In the context of the discussion later in this paper, a middle-class South Asian in the United States will differ significantly from his or her counterpart living in South Asia.

${ }^{5}$ Taken from the SAARC web site, http://www.saarc-sec.org/main.php?id=13\&t=7.1.

${ }^{6}$ In particular, see the various South Asia Human Development Reports (2000-03) published by the United Nations Development Programme. See also Singh (2001) for an interpretive essay comparing the countries of South Asia in terms of their economic policies and development outcomes.

${ }^{7}$ See Kelkar (2002) and Tuljapurkar (2002) for some comparisons of South Asia to other countries, and for more detailed demographic data and projections.
} 
met, then this demographic segment will tend to boost consumption and saving in these countries, reinforcing the impact of rising per capita incomes. ${ }^{8}$

Ultimately, it will be economic growth that enables improvements in broader human development indicators, which go beyond measures of average income or spending power. The 1990s and after have been a period where growth rates not only increased, but appeared to do so in a more sustainable manner than in previous boom periods. This improvement in income levels, following on earlier growth, did begin to affect broader measures of well-being. Table 3 summarizes this impact through trends in the United Nations Development Programme's (UNDP) Human Development Index (HDI). The 1990s do not appear to have been any better than the 1980s in terms of HDI improvements, but certainly they were a period of some consolidation of developmental gains in South Asia. The 2002 figures indicate some setbacks in improvement for Pakistan and Sri Lanka, relative to 2000, but the period is too short to identify any trend. The last column indicates the fairly high correlation of the HDIs with per capita income levels, since the rank differences are small. At the same time, it suggests that average income is not the sole factor in determining overall well-being. For example, Bangladesh, behind India in infant mortality in 1990, has since overtaken its richer neighbor (Drèze, 2004). This last theme is taken up again in section 5.

\section{The Middle Class and its Role}

The South Asian middle class has received attention primarily since the 1990s, as a consuming class benefiting from the results of economic liberalization. Given the relative poverty of Bangladesh, and the greater openness of Pakistan to imports throughout its history, attention has focused particularly on India's post-liberalization middle class and its changing consumption patterns. Clearly, the pre-liberalization policy regime had led to an under-provision of variety as well as quality: this is evidenced by substantial increases in both variety and quality of goods over the last 15 years, and by consumers eagerly taking advantage of these new supply conditions. The size of the potential Indian market also makes it attractive to firms, and hence to market researchers. However, as we illustrate later in this section, similar attention is now being paid to the middle class in Pakistan and Bangladesh.

How is one to understand the term "middle class," in the context of economic development? It can encompass attitudes and norms, as well as spending power. Although only the latter criterion can be straightforwardly applied, attitudes and norms also matter. This is illustrated by a recent detailed analysis of the size and makeup of India's middle class (Sridharan, 2004). Sridharan surveys theories of the middle class in the context of India's political economy, and attempts to construct an empirically

\footnotetext{
${ }^{8}$ Writing about India in particular, Kamath (2005) puts it picturesquely as follows: "By the year 2015, according to one account, when the new millennium's first generation of leaders will have taken over, people under twenty will make up 55 per cent of the total population or roughly 580 million. It is a frightening thought. It is this youthful population that one has to cater to. Does anyone understand the psyche of this population? What is it that it wants? What are its value systems?”
} 
workable definition, using data from the Market Information Survey of Households (MISH) data set of the National Council of Applied Economic Research (NCAER, 2003). He offers alternative definitions and estimates based on income cut-offs alone, as well as income combined with occupational cut-offs: we do not go into the details of his discussion and definitions, but report some of his numbers below, for comparison.

Sridharan discusses mainly Marxist and post-Marxist theories of the middle class, including both positive and negative aspects of their presumed social role. Das (2002, 2004) traces the idea of the positive role of the middle class back to Aristotle. He attributes to Aristotle the idea that "a good society is one where the middle class outnumbers everyone else," (Das, 2004) and in his earlier work he discusses the brashness of the new, business-oriented middle class in India, contrasting it with the older middle class, primarily made up of those in government service: his positive image of the middle class seems to be based on entrepreneurial energy and attitudes. Interestingly, Aristotle, in his Politics (Part IV), begins with a concept of the middle class defined by moderate or "mean" material prosperity, but goes on to argue that a wide set of virtuous behavioral traits flow from this median position in the class hierarchy. These virtues include willingness to rule without being over-ambitious, respect for authority, good fellowship, and reduced envy. These claims are clearly over optimistic, but it is striking how close Aristotle's conception is to modern normative discussions of the role of the middle class. ${ }^{9}$

While the estimated size of the middle class will depend on the precise definition used, the range of estimates is useful to lay out. Sridharan offers several alternative measures for India. Using a broad income criterion (above Rs. 35,000 household income, in 199899 Indian rupees - less than US $\$ 1000$ at that time), he estimates the middle class as comprising almost 26\% of all Indian households, or about 250 million people in 1998-99, up substantially from $14 \%$ and 113 million people in 1992-93. He goes on to break these totals down by occupational categories as well. Using an income band of US \$2,000 to US $\$ 4,000$, another estimate places the Indian middle class at about 300 million. ${ }^{10}$ One can take such numbers as reasonable upper bounds on the size of the middle class in India. Estimates for Pakistan and Bangladesh also exist, though they are less precisely constructed, and less emphasized in the media. Using purchasing power figures, Ishrat Husain, Governor of the State Bank of Pakistan, has been quoted as estimating a 30 million strong middle class in that country in 2003, with per capita incomes of \$8000$\$ 10,000 .{ }^{11}$ This represents about $18 \%$ of the population. At the other extreme, a much lower estimate, for the year 2000, is about 7 million people, or less than $5 \%$ of the population (Senauer and Goetz, 2003). Two available estimates for Bangladesh are

\footnotetext{
${ }^{9}$ In particular, both Mishra (1995) and Varma (1998) chastise the post-liberalization middle class in India for not possessing the Aristotelian virtues, while Das (2002), as noted, is more sanguine.

${ }^{10}$ This figure is reported in Basu (2003), without attribution. If one takes account of growth and differences in base year, the number is not out of line with Sridharan's, and the source is probably also the NCAER, which is the main compiler of such estimates in India.

${ }^{11}$ See http://encyclopedia.laborlawtalk.com/Pakistan, and similar Internet reports, based on a speech delivered by Dr. Husain.
} 
toward the lower end of the scale, 6 and 13 million people respectively, ${ }^{12}$ partly reflecting Bangladesh's lower average incomes.

Whatever one may think of particular estimates of the size of the middle class, it is clear that, in all these countries, rising incomes, new attitudes, and, most of all, changes in availability of goods and credit, together with greater competition, are altering consumption patterns. Table 4 provides one quantitative example for India, based on a survey of 10,000 four-member urban families by KSA Technopak, an Indian management consultancy firm. ${ }^{13}$ In addition to their quantitative impact on changes in consumption patterns, changes in attitudes are typically noted as significant in themselves. At the extreme, one has the perspective embodied in a quote from an Indian middle-class consumer, "I can't resist buying newer models of electronic goodies” (Basu, 2003), but the changes are more far-reaching than just an impulsive desire to consume more, and sooner rather than later. They include a greater awareness of, and aspiration for, developed country lifestyles and consumption; greater attention to personal convenience and individuality; greater willingness to experiment and question traditional modes of behavior; and greater optimism about the future. ${ }^{14}$ Openness to foreign trade has helped bring about these changes, as has the rise of India as a center for outsourced back-office services. Perhaps the globalization of visual media has had the biggest impact, with American soap operas with titles like "Santa Barbara” becoming popular viewing for segments of the urban middle class. The end result of the change in attitudes has been dubbed, "the new, improved Indian consumer," (Bijapurkar, 2003), with parallels in Pakistan and Bangladesh (e.g., Subohi, 2004; Lawson, 2002).

Setting aside discussion of inequality and poverty - and the limited extent of the population that enjoys the above consumption patterns ${ }^{15}$ - till the next section, we next consider the possible growth consequences of the changes that have been briefly noted above. Informal commentaries (e.g., Basu, 2003) on booming middle class consumption note that consumer spending boosts aggregate demand and stimulates the economy, but this is a short run effect, and not one that necessarily implies higher growth. Observers also worry about the sustainability of these levels of consumption, and the negative impact on savings, and hence on investment. ${ }^{16}$ Interestingly, in the United States, a lack

\footnotetext{
${ }^{12}$ The lower estimate comes from Hussain and Ara (2004), while the higher number is calculated by economist Devapriya Bhattacharya, quoted in Lawson (2002). Both sources use simple income cut-offs. ${ }^{13}$ For a discussion of Pakistan's corresponding middle class consumption boom, see, for example, Subohi (2004).

${ }^{14}$ For further illustration, see, for example, Kamath (2005), Jain (1993), Basu (2003), Herbig (1997) and Moore (1995). A recent analysis, combining quantitative and qualitative aspects of changing consumer attitudes and behavior, is provided by Bijapurkar (2003). For similar observations on Pakistan, see Subohi (2004). On Bangladesh, see Living Portals News (2004) and Lawson (2002) as illustrations. Kamath uses a 2003 survey made on Indian youth by Taylor Nelson Sofres (TNS), an Indian market research agency, and argues that consumption patterns have changed more than have deeper attitudes towards parents, marriage and religion.

${ }^{15}$ It is worth remarking, however, that even in 1992-93, India's National Council for Applied Economic Research (NCAER), in its regular household consumption survey, found that households just above the poverty line bought millions of transistor radios, electric fans, wrist watches, flashlights, pressure cookers, bicycles and black and white televisions. See Rao and Natarajan (1994).

${ }^{16}$ In addition to the references in Basu (2003), see also Subohi (2004).
} 
of savings in recent years has been cushioned by borrowing from abroad, and this is certainly a route that developing countries have taken in the past, but the risks are always greater for them. New growth theories go beyond considering homogeneous investment as a driver of growth (where diminishing returns will always set in) to emphasize the importance of technical progress, embodied in new varieties of capital and consumption goods, in driving long run or sustained economic growth. ${ }^{17}$ These models typically assume homogeneity of consumers, but Sarkar (1998), in an important paper, shows how demand thresholds can matter for growth, ${ }^{18}$ and how a sufficiently large middle class can be crucial in enabling growth to occur. In Sarkar's model, there are three classes of income earners: rich, middle class and poor. Having a large enough middle class is crucial for generating sufficient demand and profits to drive innovation, which in turn creates economic growth. Both the size and the consumption pattern of the middle class matter for growth in this case. Thus, this analysis provides a formal case for the positive impacts of increasing middle class consumption on South Asian economic growth.

What does this discussion of South Asian economic development, and the role of the middle class, tell us about the "idea of South Asia?” Middle class aspirations of better lives, based on higher and more varied consumption, seem to have become a common factor across the region, for those who are able to participate in economic growth. ${ }^{19}$ Recovering a trajectory of material progress - perceived as halted in the colonial period was always an important component of South Asian nationalism, but it was tempered, at least in its Indian version, by suspicion of modernity and foreign influences. The middle class in India seems to have gone a long way towards reconciling itself to the pursuit of happiness through consumption, with private enterprise playing the role of wish fulfillers. This ethos seems to also be present in India's largest neighbors, though in a more restricted way. Will a South Asian middle class, reared on an eclectic mix of indigenous and Western influences, comfortable with consumption levels that might have seemed luxurious a decade ago, form the core of a new idea of South Asia - one of economic progress towards developed country standards of living?

\section{Inequality and Heterogeneity}

A key debate in the process of economic reform in India has been that of the inclusiveness of that process. Jean Drèze, for example, puts the problem quite bluntly: "The gains of faster growth have been largely captured by the privileged. The poor, for their part, barely manage to continue their slow exit from hunger and misery.” (Drèze, 2004). Drèze compares India unfavorably with Bangladesh in terms of progress in key human development indicators. On the other hand, Pakistan lags behind India in many of

\footnotetext{
17 See, in particular, Romer (1990) and Grossman and Helpman (1991).

${ }^{18}$ A similar point is made by Murphy, Shleifer and Vishny (1989a) in the context of a static model. This idea is also related in broad terms to the 'big push' view of development advanced in the 1940s by Rosenstein-Rodan - see Murphy, Shleifer and Vishny (1989b) for detailed references and a formal model.

${ }^{19}$ If India is a role model in some respects for its South Asian neighbors, China is the guiding star for all of them. For example, Subohi (2004) begins his piece with, "Some sixteen million urban middle class earners in Pakistan have joined their counterparts in India and China in the making of the 'consumer boom' in Asia.”
} 
these dimensions of progress. In all three countries, there is a perception that a minority, with access to the best education, social networks and good jobs, is racing ahead and leaving the rest of society behind. ${ }^{20}$ In India, the last general election brought to power a coalition with a program of explicitly addressing the needs of the disadvantaged and poor. Yet, though the "elitist orientation of public policy in India has intensified," (Drèze's words) the rhetoric of policies to help the poor goes back over five decades, without adequate progress. One problem may be that these policies have been incorrectly formulated. For example, in Sarkar's model, transfers from the rich to the middle class or the poor actually decrease long run growth. In his formulation, the only feasible way to increase the growth rate is to promote the poor to the middle class by permanently increasing their productivity, through education, for example. Such policies have been relatively under-implemented in South Asia: the reasons for this may be structural.

A good place to begin examining the structural factors that may constrain and bias economic policy is the income distribution. Table 5 provides data on income distribution (actually based on consumption data) for the five large South Asian nations. The Gini index provides a summary measure of inequality, while the quintile shares provide a more disaggregated picture. Of course, all the data may be subject to some misreporting, particularly at higher levels of income and consumption. What is most striking about the data is that they are so similar across countries. While Nepal and Sri Lanka have somewhat higher Gini indices, they do not indicate significantly higher inequality. Certainly, any casual view of Pakistan as a more unequal economy is not borne out in these data. ${ }^{21}$ The consumption shares are also quite similar across countries. In fact, the income distributions suggested by the data are not more unequal than those of the United States or United Kingdom.

The aggregate data on trends in inequality also show considerable stability. For India, the Gini index in 1960 was almost identical to that in 2000 (Bhalla, 2002, Table 3.1). For Pakistan, there was a slight increase in the Gini index from 1984-85 to 1998-99 (especially toward the end of that period), but the difference was marginal (World Bank, 2002, Figure 2). In the case of Bangladesh, quintile share data for the 1970s through the 1990s suggest a small secular decline in inequality. ${ }^{22}$ Overall, then, aggregate data do not suggest any marked increase in income (or consumption) inequality.

There remains the possibility that collection methods, accuracy or inherent biases in aggregate data have changed over time. In India, in particular, changes in data collection

\footnotetext{
${ }^{20}$ On India, see, for example, Baldauf (2004), who states, "many middle class and poor Indians complain that the boom has benefited a fortunate few and left ordinary Indians bearing the loss of 1.3 million jobs cut from the government bureaucracy over the past decade.”

${ }^{21}$ However, Easterly (2001) argues that "Pakistan systematically underperforms on most social and political indicators -- education, health, sanitation, fertility, gender equality, corruption, political instability and violence, and democracy -- for its level of income. It systematically under-performs on improvements in these indicators for its rate of GDP per capita growth over time." He calls this "growth without development," notes large inequalities between men and women, between urban and rural areas, and between regions, and blames elite domination and ethnic division.

${ }^{22}$ This statement is based on quintile shares as reported in income distribution tables in World Bank World Development Reports from various years.
} 
methodology led to a re-examination of aggregate data on poverty and inequality. Deaton and Drèze (2002) adjust for differences in collection methodology, and find evidence of increasing urban inequality between $1993-94$ and $1999-2000 .{ }^{23}$ Data from the NCAER (reported in Bijapurkar, 2003) suggests a similar story for rural as well as urban households, with the highest income class gaining the most from 1995-96 to 1998-99, and the poorest actually doing worse (Table 6). Finally, Banerjee and Piketty (2001) use income tax records to document very large increases in income among the very highest income earners, i.e., the top one per cent. ${ }^{24}$ In this respect, India may be becoming more like Pakistan, with a small, very wealthy elite, whose enrichment does not much affect the overall income distribution.

The picture that begins to emerge from considering inequality is one that is consistent with the freer operation of market forces. Removing inefficiencies and constraints benefits most people, but those who are already favorably positioned gain the most. Those who are already marginalized, at the bottom rung of the ladder, may be worse off, absent appropriate policy adjustments. Examinations of regional inequality in India tell a similar picture, with most regions growing, the best-positioned gaining the most, and some being left behind almost completely. ${ }^{25}$ Based on disaggregated data, Deaton and Drèze (2002) suggest that localized impoverishment is a real phenomenon in India. As Drèze (2004) points out, these changing patterns of inequality are not a necessary consequence of economic reform. The states of India have long differed in social outcomes, beyond what might be explained by differences in income levels. For example, Kerala is a long-term example of positive public policy interventions, with high life expectancy and literacy rates. Himachal Pradesh, Madhya Pradesh, Rajasthan and Tamil Nadu are all cases of Indian states where significant improvements in health and nutrition have recently been achieved (Drèze, 2004; Singh et al, 2003). And, as noted earlier, Bangladesh's achievements in certain human development measures outstrip those of India, indicating the importance of policy priorities and implementation.

One may trace differences in performance with respect to fulfilling basic needs such as primary education, nutrition and health care to differences in public policy. This leads one to examine the processes that determine policy, and the structural factors that determine these processes. Implicit (or explicit) in the writing of Drèze (2004) and many others is a view of policy as determined by an elite, one that is benefiting greatly from economic reform, liberalization and globalization. In Drèze's view of India, "the poor count for very little in Indian politics. They are on the margin of the democratic process."

\footnotetext{
${ }^{23}$ Bhalla (2004) disputes this conclusion, stating, "The problem with the DD study is that it does not compare like with like. DD compare unadjusted inequality for 1993-94 with adjusted inequality for 199900 , whereas they should be comparing adjusted inequality for both the years. If this is done, using exactly the DD method of adjustments, then one finds that there is virtually no change in inequality between 199394 and 1999-00.” For conclusions more in line with those of Deaton and Drèze, see Jha (2000).

${ }^{24}$ Two qualifications to these observations are in order. First, the NCAER data is not a longitudinal study, so the samples are different in the two years. Second, the Banerjee-Piketty results may be skewed - the share of the top two percent of income tax filers has not changed so dramatically. I am grateful to Surjit Bhalla for both these points.

${ }^{25}$ For a summary of studies on regional inequality in India, as well as some newer, disaggregated results, see Singh et al (2003).
} 
To the extent that there is a wide gulf between rich and poor, it may be expected that the rich will choose or influence policies to favor themselves to the extent they can. This view emphasizes the consequences of a kind of polarization, which may enhance distributional conflict. ${ }^{26}$

The problem faced by South Asian societies, however, may be deeper and more subtle than simply one of class conflict or income polarization. South Asia's middle classes do not just ignore the plight of the poor. Nor are the rich necessarily villains in this respect. ${ }^{27}$ The middle class, while consuming the newly available cornucopia of private goods, continues to be satisfied with levels of public goods that are, in many cases, appallingly low. What constitutes a public good must be clarified - in some cases, goods that are government-provided in South Asia are not truly public goods in the sense of being nonrival or non-excludable. Often, however, there is some non-rival or non-excludable element to these goods, even if they are not "pure" public goods in the sense of economic theory: all kinds of infrastructure, and goods and services, such as primary education or basic health, where there are strong externalities, come under this fuzzy class. The latter are also termed "merit" goods in the traditional public finance literature. ${ }^{28}$ They are also the kinds of goods where, following Sarkar's analysis, better provision to the poor may help lift them into the middle class. Hence, understanding the collective action issues in the provision of these goods is essential for understanding future growth prospects, and the limits of the idea of South Asia as it has evolved over the last decade or so.

Since public goods are typically funded through taxes, one possible indicator of a lack of social consensus, or of institutional mechanisms to implement a consensus, with respect to providing these goods is the ratio of government revenue to GDP. Table 7 provides figures for 1999 for the five main countries analyzed here, with averages for low income countries for comparison. One sees that India, especially, does poorly on this criterion, with government revenues as a percentage of GDP below the average of low income countries - whose average per capita national income is somewhat lower than India's. Bangladesh also does somewhat poorly, but Pakistan does surprisingly well by this measure. ${ }^{29}$ Several factors are missing from these numbers: government expenditure in relation to GDP (all these countries run budget deficits), who benefits from these expenditures, and the incidence of tax burdens. In particular, higher taxes might be used for subsidizing the middle class, rather than providing public or quasi-public goods that benefit the masses.

\footnotetext{
${ }^{26}$ Esteban and Ray (1999) provide a formal analysis of distributional conflict, and references to the theoretical literature. Sri Lanka provides a useful case study of distributional conflict and the impacts of initial conditions as well as economic policies: see, for example, Abeyratne (2001).

${ }^{27}$ Gurcharan Das puts it thus: "Men like Azim Premji of Wipro and Narayana Murthy of Infosys are "secular ascetics," who live frugally and engage in philanthropy. So for the first time in modern India, the rich are looked up to with pride and reverence.” (Das, 2004).

${ }^{28}$ See Musgrave (1959). While Musgrave introduced the term, it can be traced back to Adam Smith. However, there have been some controversies over the precise meaning, and the externality perspective is analytically the clearest, tying in with public goods, which can also be formulated in externality terms.

${ }^{29}$ The figures reported here are for central government revenues, and so underestimate the performance of India, where the states also raise substantial tax revenue. Bhalla (2005) has challenged the view that India undertaxes, but Rao (2005), in a subsequent analysis, definitively supports the view presented here.
} 
More direct evidence for the determinants of spending on public goods in India comes from an innovative analysis by Banerjee (2004), who empirically tackles the causes of the kinds of regional differences highlighted by Drèze and others. ${ }^{30}$ He notes variations in public goods outcomes within India's states, as well as across them, and explores the impact of geography, history, land-tenure systems, caste and religion. Looking at the availability of various health and education services, and some basic infrastructure goods, there is evidence that socio-economic fragmentation, as well as having a high percentage of scheduled castes or tribes, reduces the availability of some public goods. ${ }^{31}$ While there are some puzzles in the results, and Banerjee is cautious in his interpretations, these kinds of findings are indicative of the problem that seems to have faced South Asia since independence: a lack of social identification as a hindrance to inclusive collective action. Note that Sarkar's model has no role for public goods, but one can add them. That model can be extended by making the productivity of the private sector depend positively on the level of public goods such as infrastructure. If heterogeneity and inequality lower the equilibrium level of public goods, another link between income distribution and growth exists, in addition to that explored by Sarkar.

There is much more that can be said about the impact of social heterogeneity and inequality on economic outcomes. Instead, what I want to highlight here is the following idea. A true middle class "growth revolution," as envisaged by some proponents and supporters of economic reform, will require attention to a broader sphere than simply the increased consumption of private goods. Until the middle class also demands, or helps finance, higher levels of public and quasi-public goods, especially those that are accessible by the entire population or consumed by the poor, one cannot be completely optimistic about the prospects of a new idea of South Asia, built on material prosperity. Unfortunately, there is a tendency for those who emphasize the needs of the poor to be disapproving of lavish consumption, and even of liberalization in general. This attitude misses the point, and diverts attention from the key issues. ${ }^{32}$ Nevertheless, the above argument suggests that South Asia's expanding middle class needs to establish a commonality in addition to (not instead of) the consumption of private goods, toward some shared social vision, for growth to be sustained. How is this to be done?

\footnotetext{
${ }^{30}$ See also Banerjee and Somanathan (2001), and Banerjee, Iyer and Somanathan (2004) for additional empirical analysis for India, on this topic. Interestingly, Alesina and La Ferrara (2000) consider a formal model in which individuals prefer to interact with others who are similar to themselves in characteristics such as income or race. They focus on the relationship between heterogeneity and participation, and go on to empirically test their model with United States data, finding that, indeed, heterogeneity reduces participation.

${ }^{31}$ Banerjee finds some evidence that a higher proportion of Brahmins (historically the highest caste) is associated with higher levels of more "elite" public goods such as paved roads and electricity for domestic use.

${ }^{32}$ Those who create wealth, and are paid well for it, cannot simply be denied enjoyment of the fruits of their labor. While multimillionaires like Azim Premji of Wipro and Narayana Murthy of Infosys may live relatively frugally, and set an example for their employees, they pay handsomely for talent and hard work, and they do not tell their employees how to spend their money.
} 


\section{Building "South Asia"}

Shared social visions can be expressed through kinship, cultural, and religious ties. Each of these has limitations as well as benefits. Some version of a state, a sarkaar, is required beyond these associations, and various forms of government have been societal responses. However, it is widely accepted that the quality of governance in South Asia is relatively poor. "Relative" here can mean as compared to a developed country benchmark, or to some average of developing countries. Table 8 provides some data on different measures of governance, and recent trends, with the United States and China used as alternative benchmarks, since the indices used have no natural, readily interpretable magnitudes. Clearly, even this range of indices cannot capture all the nuances of governance, but the quantities do seem to indicate that the popular view of governance in South Asia accords with reality. Nor, over this time period, 1996 to 2002, are there any indications that matters are improving.

When governance is poor, the danger is that those who can afford to will effectively secede from society, and arrange for private or club-like provision of public or quasipublic goods. This can happen even when governance is not an issue - the rich or privileged may simply choose to opt out of paying for public goods that chiefly benefit "others." This is happening to some extent in the United States, as income inequalities and racial heterogeneities both increase. In South Asia, it is an even more tempting route for the middle class, since they can now buy their way out of consuming public or quasipublic goods - using cars instead of public transport, sinking backyard wells, and sending their children to private schools. In fact, none of these behaviors is new - just the numbers who can take this route are increasing. The result is not just greater inequality, but also an erosion of social capital, or organizational and societal infrastructure.

An alternative response to a negative opting out is to bypass the government but still try to provide public goods to the poor, through nongovernmental organizations (NGOs).

NGOs as a response to governance failures have certainly flourished in some areas, such as providing primary education and basic health needs. Of course, they are subject to their own accountability problems, limited in their resources, and can vary widely in quality and effectiveness. Nevertheless, they have been an important alternative in South Asia, and in Bangladesh, in particular, are at least part of the explanation for the fact that Bangladesh, with lower income and worse governance measures has done better than India in several dimensions of human development (see Tables 1 and 8). ${ }^{33}$

One of the most interesting responses to governance failures lies in social entrepreneurship models, where ownership lies with a non-profit body, but profit and self-interest motives drive actors further down the organizational chain. This approach provides bottom-line accountability, better incentives, and the possibility of sustainability (and hence scalability) through self-financing. Organizations providing rural Internet access and services, such as n-Logue and Drishtee illustrate the potential power of this

\footnotetext{
${ }^{33}$ A colleague in the economics profession once stated this situation more strongly, that Bangladesh was effectively being run by NGOs.
} 
approach, for a certain range of services. ${ }^{34}$ The key here is in reducing transaction costs, to make services more affordable, and hence accessible to broader populations. In the case of some basic health and education services to rural areas, these transaction costs are often one barrier to effective delivery, and the combination of information technology with a low-cost organization can be effective. These organizations appear to serve bridging roles between those who want or need particular services, and a mix of private corporations, NGOs and government agencies that wish to serve them. At the same time, they, as well as NGOs, must be recognized as complements to government as the focus of collective action, rather than as substitutes.

The reason why government has an essential role is well-known - there are free-rider problems associated with voluntary participation, so members of a democratic society must agree to allow themselves to be taxed. The low tax revenue-GDP ratio in India ultimately represents a failure on this front, and, at least partly, reflects a lack of identification of the middle classes with the rest of society. Another causal factor is the inefficiency of government, since individuals are more reluctant to pay taxes when they think the money will not be well spent. One possible approach to improving efficiency and creating a closer link between the costs and benefits of tax payments, as perceived by citizens, is to decentralize government so that at least the geographical locus of beneficiaries and payers matches more closely. ${ }^{35}$ In addition to this classic economic rationale (going back to Knut Wicksell a hundred years ago), there is the importance of participation in democracy. Drèze (2004) puts it nicely, as follows: “[D]emocracy is not just a matter of voting. It is a question of sustained, informed participation in democratic institutions, such as village assemblies, citizens' associations, trade unions and political parties.” Here he is talking about the poor, highlighting the difficulties they face in participating on "an empty stomach," but the middle class in South Asia also suffers from the same lack of participation, even with full stomachs. Sustained, informed democratic participation is a key aspect of building social capital.

Sunil Khilnani (1997), in his conception of “the idea of India,” offers three perspectives: that of India as a modern state, that of an experiment in democracy, and that of a stratified society confronting "the imperatives of modern commercial society." His conclusion is ultimately to argue for acceptance of diversity over the exclusiveness of Hindutva, but he seems to view participation in the global economy with suspicion, and with the traditional disdain of the traditional Indian intellectual. ${ }^{36}$

\footnotetext{
${ }^{34}$ See Singh (2004) for a detailed analysis of rural information technology initiatives in India. For a somewhat different perspective on the benefits of bringing market access to the "bottom of the pyramid," see Prahalad (2004).

${ }^{35}$ See Rao and Singh (2003) for an analysis of local government reform in India that develops this point, as well as other economic arguments for decentralization.

${ }^{36}$ He does this through his rhetoric, rather than any specific analytical arguments. For example, he asks, "Is international trade a public good for all participants? Or is it more accurately seen as a zero-sum game...?” (p. 206). And in his introduction, he broadly states, that India's encounter with "the imperatives of modern commercial society" is "presumed somehow to link a political order that enshrines individual rights and representation to an economic system of private property rights and market exchange -but it stands under permanent threat of being unable to reproduce itself, and is fundamentally unstable.” (Khilnani, 1997, p. 5)
} 
The argument offered in this paper is different. Participation in the global market economy brings prosperity, particularly to those who are initially well-positioned. In the long run, however, sharing the fruits of this initial prosperity more broadly may be crucial for true development. Consider the contrast between Latin America, which shook off colonial masters in the $19^{\text {th }}$ century, but not colonialist attitudes towards the majority of its population, and East Asia, where economic growth and human development have been both more inclusive and much greater.

Hence, an inclusive path of economic progress in South Asia does not require a rejection of the market, or of material consumption, but it does require attention to improving public institutions and meeting citizens' basic needs through them. Furthermore, the issues with respect to political institutions are not just those of abstractions such as "the state" or "democracy," but the detailed structures that determine government functioning and political participation, such as tax assignments, bureaucratic incentives, and electoral arrangements. Reinventing these institutional structures is a significant part of building social capital in the region. This is where South Asia's middle classes might usefully turn their attention and their expectations of improvement.

\section{Conclusions}

The idea of South Asia is one that must, by its very definition, transcend national and religious boundaries. Given the role played by India, and its relatively stable democratic system, some version of pluralistic democracy can be accepted as an important part of the idea of South Asia. Despite the conflicts and setbacks that the region has faced, democratic institutions, particularly those built from the ground up (but within the topdown framework inherited from the colonial power), promise to be very resilient in South Asia, albeit in varying forms. Ultimately, however, the idea of South Asia relies on some degree of shared identity. If religion, language and nationality are not broad enough, then what else can fill the breach? As in the case of post-World War II Europe, shared economic progress can provide a commonality of purpose as well as perspectives. The growing middle class of South Asia, with its rising aspirations and expectations, can be an important driver of this process. To achieve this, one can make a positive theoretical argument that the middle class will need to go beyond a preoccupation with private consumption, and provide resources for more inclusive growth and development. This will create a sustainable idea of South Asia.

\section{References}

Abeyratne, S. (2001), Economic Roots of Political Conflict: The Case of Sri Lanka, Working Paper, Department of Economics, Research School of Pacific and Asian Studies, ANU 
Alesina, A., and E. La Ferrara, (2000), Participation in Heterogeneous Communities, Quarterly Journal of Economics, vol. 115(3), pp. 847-904, August.

Aristotle (2005), Politics, translation by Benjamin Jowett, available at http://classics.mit.edu/Aristotle/politics.html, accessed April 22, 2005.

Banerjee, A. V. (2004), Who is Getting the Public Goods in India? Some Evidence and some speculation, in India's Emerging Economy, ed. K. Basu, Cambridge, MA: The MIT Press, pp. 183-213.

Banerjee, A. V., L. Iyer and R. Somanathan (2004), History, Social Divisions and Public Goods in Rural India, MIT working paper.

Banerjee, A. V., and R. Somanathan (2001), Caste, Community and Collective Action: The Political Economy of Public Good Provision in India, MIT working paper.

Basu, I. (2003), India's Growing Urge to Splurge, Asia Times Online, http://www.atimes.com/atimes/South_Asia/EH22Df01.html, accessed January 4, 2005.

Baldauf, S. (2004), Boom Splits India's Middle Class, The Christian Science Monitor, from the May 13, 2004 edition - http://www.csmonitor.com/2004/0513/p01s04wosc.html, accessed January 4, 2005.

Bhalla, S. S. (2003), Imagine There's No Country: Poverty, Inequality, and Growth in the Era of Globalization, New Delhi: Penguin.

Bhalla, S. S. (2004), In(equality) We Believe, August 21, http://www.rediff.com/money/2004/aug/21guest.htm, accessed January 4, 2005.

Bhalla, S. S. (2005), Aamdani Athani, Kharcha Rupaiyya, Business Standard, January 22, 2005.

Bijapurkar, R. (2003), The New, Improved Indian Consumer, Business World, 8 December, pp. 28-36.

Das, G., (2002), India Unbound: The Social and Economic Revolution from Independence to the Global Information Age, Anchor Books, New York.

Das, G. (2004), The Respect They Deserve, Time, Asia, December 6, 2004 / Vol. 164, No. 23

http://www.time.com/time/asia/magazine/printout/0,13675,501041206-832319,00.html, accessed January 4, 2005.

Deaton, A. and J. Drèze (2002), Poverty and Inequality in India: A Re-Examination, Economic and Political Weekly, September 7, pp. 3729-3748. 
Drèze, J. (2004), Don't Forget India's Poor, December 6, 2004 / Vol. 164, No. 23, http://www.time.com/time/asia/magazine/printout/0,13675,501041206-832318,00.html, accessed January 4, 2005.

Easterly, W. (2001), The Political Economy of Growth without Development: A Case Study of Pakistan, Paper for the Analytical Narratives of Growth Project, Kennedy School of Government, Harvard University, June.

Esteban, J. and D. Ray (1999), Conflict and Distribution, Journal of Economic Theory, 87, pp. 379-415.

Grossman, G. and E. Helpman (1991), Innovation and Growth in the Global Economy, Cambridge, MA: MIT Press.

Herbig, P. (1997) India’s Middle Class: Real or Fiction? Feasible or Not?, http://www.geocities.com/Athens/Delphi/9158/paper21.html, accessed January 4, 2005.

Hussain, S.S. and F. Ara (2004), Bangladesh Retail Food Sector Report, USDA Foreign Agricultural Service, http://www.fas.usda.gov/gainfiles/200402/146105367.pdf, accessed April 25, 2005.

Jain , S.C. (1993), Marketing Evolution in Developing Countries. The Unfolding of the Indan Market, Binghampton, NY: Haworth Press.

Jha, R. (2000), Reducing Poverty and Inequality in India: Has Liberalization Helped?, WIDER Working Paper No. 204, November.

Kamath, M.V. (2004), A Changing, Moving, Resurgent India, http://samachar.com/features/130105-features.html, accessed January 21, 2005.

Kelkar, V. (2002), South Asia in 2020: Economic Outlook, in South Asia in 2020: Future Strategic Balances and Alliances, Ed. M.R. Chambers, Carlisle, PA: Strategic Studies Institute, pp. 63-104.

Khilnani, S. (1997), The Idea of India, New York: Farrar Strauss Giroux.

Lal, C.K. (2003), The Necessary Manufacture of South Asia, Himal South Asian, January, Asia Special, http://www.himalmag.com/2003/january/asia_special_2.htm, accessed April 25, 2005.

Lawson, A. (2002), Good times for bourgeois Bangladeshis, June 1, http://news.bbc.co.uk/1/hi/world/south_asia/2018535.stm, accessed April 25, 2005.

Living Portals News (2004), Bangladesh gets first Western-style mall in sign of growing Middle Class, Tuesday September 21, http://living.news.designerz.com/bangladesh-getsfirst-western-style-mall-in-sign-of-growing-middle-class.html, accessed January 4, 2005. 
Mishra, P. (1995), Butter Chicken in Ludhiana, New Delhi: Penguin India.

Moore ,P. (1995), The Burgeoning of the Bourgeoisie. Director, 48(10) 36-42, May.

Murphy, K.M., A. Shleifer, and R.W. Vishny, (1989a), Income Distribution, Market Size and Industrialization, Quarterly Journal of Economics, 104: 537-564.

Murphy, K.M., A. Shleifer, and R.W. Vishny, (1989b), Industrialization and the Big Push, Journal of Political Economy, 97(5) October: 1003-1026.

Musgrave, R.A. (1959), The Theory of Public Finance, McGraw-Hill Book Company, New York.

NCAER (2003) India Market Demographic Report 2002, NCAER, New Delhi.

Prahalad, C.K. (2004), The Fortune at the Bottom of the Pyramid, Philadelphia, PA: Wharton School Publishing.

Rao, M.G. (2005), Should Indians pay more in taxes?, Business Standard, February 12, available at http://www.business-

standard.com/search/storypage_new.php?leftnm=lmnu5\&leftindx=5\&lselect $=1$ \&autono= 180612, accessed April 27, 2005

Rao, M.G., and N. Singh, (2003), How to Think About Local Government Reform in India, in Economic Reform and the Liberalization of the Indian Economy: Essays in Honour of Richard T Shand, ed., K.P. Kalirajan. London: Edward Elgar., pp. 335-390

Rao, S.L., and I. Natarajan (1994), Markets for Consumer Products in India, Delhi: Global Business Press.

Rao, S.L., and I. Natarajan (1996), Indian Market Demographics: The Consumer Classes, Delhi: Global Business Press.

Romer, P. M. (1990), Endogenous Technological Change, Journal of Political Economy, 98(5), pp. S71-S102.

Sarkar, A. (1998), Endogenous Growth and the Size of the Market, Keio Economic Studies, 35 (1), pp. 29-44.

Senauer, B. and L. Goetz, The Growing Middle Class in Developing Countries and the Market for High-Value Food Products, Working Paper, Department of Applied Economics, University of Minnesota, February, www.farmfoundation.org/documents/Ben-Senauerpaper2--10--3-13-03_000.pdf, accessed April 25, 2005. 
Singh, N. (2001), The Economies and Economics of South Asia: In Search of Lost Time. In International Encyclopedia of Social and Behavioral Sciences, South Asian Studies: Economics 22: 14631-6, eds., Paul B. Baltes and Neil J. Smelser.

Singh, N. (2004), Information Technology and Rural Development in India, in Integrating the Rural Poor into Markets, in Bibek Debroy and Amir Ullah Khan, eds., New Delhi: Academic Foundation, pp. 221-246.

Singh, N. , L. Bhandari, A. Chen and A. Khare (2003), Regional Inequality in India: A Fresh Look, Economic and Political Weekly, 38 (11), pp. 1069-1073, March 15.

Sridharan, E. (2004), The Growth and Sectoral Composition of India's Middle Class: Its Impact on the Politics of Economic Liberalization, India Review, 3 (4), pp. 405-428.

Subohi, A. (2004), Pakistan Joins Asia's Consumer Boom, Dawn, 29 November 2004, http://www.dawn.com/2004/11/29/ebr5.htm, accessed January 4, 2005.

Tuljapurkar, S. (2002), Demographic Forces in South Asia through 2050: Population, Economy, and Health, in South Asia in 2020: Future Strategic Balances and Alliances, Ed. Michael R. Chambers, Carlisle, PA: Strategic Studies Institute, pp. 105-124.

Varma, P.K. (1998), The Great Indian Middle Class, New Delhi: Viking Penguin India.

World Bank (2002), Poverty in Pakistan in the 1990s: An Interim Assessment - Summary of the Report, presented at Pakistan Human Development Forum, January 24 - 26, Islamabad. 
Table 1: South Asian Development Indicators, 2003

\begin{tabular}{|c|c|c|c|c|c|c|c|c|c|c|c|}
\hline Indicator & $\begin{array}{l}\text { Population } \\
\text { (million) }\end{array}$ & $\begin{array}{l}\text { Population } \\
\text { growth } \\
\text { (annual } \\
\% \text { ) }\end{array}$ & $\begin{array}{l}\text { Gross } \\
\text { National } \\
\text { Income } \\
\text { per capita }\end{array}$ & $\begin{array}{l}\text { Agriculture, } \\
\text { value added } \\
\text { (\% of GDP }\end{array}$ & $\begin{array}{l}\text { Electric } \\
\text { power } \\
\text { consumption } \\
\text { (kwh per } \\
\text { capita)** } \\
\end{array}$ & $\begin{array}{l}\text { Exports of } \\
\text { goods and } \\
\text { services (\% } \\
\text { of GDP) }\end{array}$ & $\begin{array}{l}\text { Fixed line \& } \\
\text { mobile phone } \\
\text { subscribers } \\
\text { (per } 1,000 \\
\text { people)* }\end{array}$ & $\begin{array}{l}\text { Mortality } \\
\text { rate, infant } \\
\text { (per 1,000 } \\
\text { live } \\
\text { births) } \\
\end{array}$ & $\begin{array}{l}\text { Literacy } \\
\text { rate, adult } \\
\text { total (\% of } \\
\text { people ages } \\
15+)^{* * *} \\
\end{array}$ & $\begin{array}{l}\text { Literacy rate, } \\
\text { adult female } \\
\text { (\% of } \\
\text { females ages } \\
15+)^{* * *}\end{array}$ & $\begin{array}{l}\text { Improved } \\
\text { sanitation } \\
\text { facilities, (\% of } \\
\text { urban population } \\
\text { with access) }{ }^{* * *}\end{array}$ \\
\hline Bangladesh & 138 & 1.7 & 400 & 22 & 94 & 14 & 13 & 48 & 40 & 30 & 71 \\
\hline India & 1064 & 1.5 & 530 & 23 & 365 & 15 & 52 & 65 & 57 & 45 & 61 \\
\hline Nepal & 25 & 2.2 & 240 & 40 & 61 & 14 & 15 & 62 & 42 & 24 & 73 \\
\hline Pakistan & 148 & 2.4 & 470 & 23 & 358 & 20 & 34 & 76 & 42 & 25 & 95 \\
\hline Sri Lanka & 19 & 1.2 & 930 & 20 & 285 & 35 & 96 & 16 & 92 & 89 & 97 \\
\hline
\end{tabular}

Source: http://devdata.worldbank.org/data-query/, accessed, January 3, 2005

Notes: * 2002; ** 2001; *** 2000 
Table 2: Demographic Indicators, 2002

\begin{tabular}{|c|c|c|c|c|c|c|}
\hline \multirow[b]{2}{*}{ Country } & \multirow{2}{*}{ Indicator } & \multicolumn{3}{|c|}{ Population Age Composition (\%) } & \multicolumn{2}{|c|}{$\begin{array}{c}\text { Dependency ratio } \\
\text { (Dependents as proportion of working-age population) }\end{array}$} \\
\hline & & $\begin{array}{l}\text { Ages } \\
0-14\end{array}$ & $\begin{array}{l}\text { Ages } \\
15-64\end{array}$ & $\begin{array}{c}\text { Ages } \\
65+\end{array}$ & Young & Old \\
\hline Bangladesh & & 36.2 & 60.5 & 3.3 & 0.60 & 0.05 \\
\hline India & & 32.8 & 62.2 & 5.0 & 0.53 & 0.08 \\
\hline Nepal & & 40.4 & 55.8 & 3.8 & 0.72 & 0.07 \\
\hline Pakistan & & 40.6 & 56.0 & 3.3 & 0.73 & 0.06 \\
\hline Sri Lanka & & 25.6 & 67.8 & 6.5 & 0.38 & 0.10 \\
\hline
\end{tabular}

Source: http://www.worldbank.org/data/wdi2004/tables/table2-1.pdf, accessed January 3, 2005, and author's calculations 
Table 3: Trends in HDI, South Asia

\begin{tabular}{lcccccccc}
\hline Country & $\mathbf{1 9 7 5}$ & $\mathbf{1 9 8 0}$ & $\mathbf{1 9 8 5}$ & $\mathbf{1 9 9 0}$ & $\mathbf{1 9 9 5}$ & $\mathbf{2 0 0 0}$ & $\mathbf{2 0 0 2}$ & $\begin{array}{c}\text { GDP per capita } \\
\text { (PPP US \$) } \\
\text { rank minus } \\
\text { HDI rank }\end{array}$ \\
\hline Bangladesh & 0.335 & 0.353 & 0.386 & 0.416 & 0.445 & 0.478 & 0.509 & 1 \\
India & 0.407 & 0.434 & 0.473 & 0.511 & 0.545 & 0.577 & 0.595 & -10 \\
Nepal & 0.289 & 0.328 & 0.370 & 0.416 & 0.453 & 0.480 & 0.504 & 11 \\
Pakistan & 0.345 & 0.372 & 0.404 & 0.442 & 0.473 & 0.499 & 0.497 & -7 \\
Sri Lanka & 0.616 & 0.650 & 0.676 & 0.697 & 0.719 & 0.741 & 0.740 & 16 \\
\hline
\end{tabular}

Sources: http://www.undp.org.np/publications/reghdr2003/Stat_tables.pdf, http://hdr.undp.org/reports/global/2004/pdf/hdr04_HDI.pdf 
Table 4: Indian Urban Middle Class Consumption Patterns

\begin{tabular}{lcc}
\hline & & \\
& $\begin{array}{c}\text { Percentage of annual earnings spent } \\
\mathbf{1 9 9 9}\end{array}$ & $\mathbf{2 0 0 2}$ \\
\hline & & \\
Groceries & 46.2 & 42.1 \\
Personal care & 6.2 & 8.8 \\
Appliances/durables & 8.6 & 5.0 \\
Clothes/footware/furnishing & 7.8 & 10.5 \\
Books/music & 5.0 & 6.7 \\
Movies/entertainment & 2.9 & 5.8 \\
Vacation/eating out & 10.8 & 15.6 \\
Savings and investments & 12.1 & 5.2 \\
\hline
\end{tabular}

Source: KSA Technopak household survey, reported in Basu (2003) 
Table 5: Inequality in South Asia

\begin{tabular}{llcccccc}
\hline Country & \multicolumn{1}{c}{$\begin{array}{c}\text { Survey } \\
\text { Year }\end{array}$} & $\begin{array}{c}\text { Gini } \\
\text { Index }\end{array}$ & \multicolumn{5}{c}{ Percentage share of consumption } \\
& & & $\begin{array}{c}\text { Lowest } \\
\text { 20\% }\end{array}$ & $\begin{array}{c}\text { Second } \\
\mathbf{2 0 \%}\end{array}$ & $\begin{array}{c}\text { Third } \\
\mathbf{2 0 \%}\end{array}$ & $\begin{array}{c}\text { Fourth } \\
\mathbf{2 0 \%}\end{array}$ & $\begin{array}{c}\text { Highest } \\
\mathbf{2 0 \%}\end{array}$ \\
\hline Bangladesh & 2000 & 31.8 & 9.0 & 12.5 & 15.9 & 21.2 & 41.3 \\
India & $1999-2000$ & 32.5 & 8.9 & 12.3 & 16.0 & 21.2 & 41.6 \\
Nepal & $1995-96$ & 36.7 & 7.6 & 11.5 & 15.1 & 21.0 & 44.8 \\
Pakistan & $1998-99$ & 33.0 & 8.8 & 12.5 & 15.9 & 20.6 & 42.3 \\
Sri Lanka & 1995 & 34.4 & 8.0 & 11.8 & 15.8 & 21.5 & 42.8 \\
\hline
\end{tabular}

Source: http://www.worldbank.org/data/wdi2004/pdfs/table2-7.pdf 
Table 6: Urban Indian Households:

Average annual growth in per capita income, 1995-96 to 1998-99 (\%)

\begin{tabular}{lrrr}
\hline Income Class & Urban & Rural & Total \\
\hline & & & \\
Lower & -10.8 & -4.5 & -5.5 \\
Lower-middle & 0.9 & 7.7 & 5.6 \\
Middle & 5.3 & 7.8 & 6.6 \\
Upper-middle & 9.9 & 8.6 & 9.3 \\
High & 21.5 & 14.3 & 18.6 \\
\hline
\end{tabular}

Source: NCAER household survey, reported in Bijapurkar (2003) 
Table 7: Government Revenues in South Asia, 1999

\begin{tabular}{lcc}
\hline Country & $\begin{array}{c}\text { Current } \\
\text { revenue, } \\
\text { excluding } \\
\text { grants (\% of } \\
\text { GDP) }\end{array}$ & $\begin{array}{c}\text { GNI per capita } \\
\text { (current US\$) }\end{array}$ \\
& & \\
\hline Low income average & 12.79 & 390 \\
Bangladesh & 9.28 & 370 \\
India & 12.01 & 440 \\
Nepal & 10.15 & 230 \\
Pakistan & 15.80 & 460 \\
Sri Lanka & 17.71 & 860 \\
\hline
\end{tabular}

Source: Source: http://devdata.worldbank.org/data-query/, accessed, January 3, 2005 
Table 8: South Asian Governance Indices

(standard errors in parentheses)

\begin{tabular}{|c|c|c|c|c|c|c|c|}
\hline Country & Index & $\begin{array}{c}\text { Political } \\
\text { stability and } \\
\text { absence of } \\
\text { violence }\end{array}$ & $\begin{array}{l}\text { Government } \\
\text { effectiveness }\end{array}$ & $\begin{array}{c}\text { Regulatory } \\
\text { quality }\end{array}$ & Rule of law & $\begin{array}{l}\text { Control of } \\
\text { corruption }\end{array}$ & $\begin{array}{l}\text { Voice and } \\
\text { accountability }\end{array}$ \\
\hline \multirow[t]{2}{*}{ United States } & 1996 & $\begin{array}{c}0.92 \\
(0.27)\end{array}$ & $\begin{array}{c}1.64 \\
(0.22)\end{array}$ & $\begin{array}{c}1.31 \\
(0.22)\end{array}$ & $\begin{array}{c}1.70 \\
(0.15)\end{array}$ & $\begin{array}{c}1.60 \\
(0.17)\end{array}$ & $\begin{array}{c}1.46 \\
(0.21)\end{array}$ \\
\hline & 2002 & $\begin{array}{c}0.34 \\
(0.21)\end{array}$ & $\begin{array}{c}1.70 \\
(0.16)\end{array}$ & $\begin{array}{c}1.51 \\
(0.18)\end{array}$ & $\begin{array}{c}1.70 \\
(0.13)\end{array}$ & $\begin{array}{c}1.77 \\
(0.16)\end{array}$ & $\begin{array}{c}1.32 \\
(0.17)\end{array}$ \\
\hline \multirow[t]{2}{*}{ China } & 1996 & $\begin{array}{c}0.23 \\
(0.27)\end{array}$ & $\begin{array}{c}0.11 \\
(0.20)\end{array}$ & $\begin{array}{l}-0.10 \\
(0.21)\end{array}$ & $\begin{array}{l}-0.43 \\
(0.15)\end{array}$ & $\begin{array}{l}-0.01 \\
(0.17)\end{array}$ & $\begin{array}{l}-1.22 \\
(0.21)\end{array}$ \\
\hline & 2002 & $\begin{array}{c}0.22 \\
(0.20)\end{array}$ & $\begin{array}{c}0.18 \\
(0.15)\end{array}$ & $\begin{array}{l}-0.41 \\
(0.17)\end{array}$ & $\begin{array}{l}-0.22 \\
(0.13)\end{array}$ & $\begin{array}{l}-0.41 \\
(0.15)\end{array}$ & $\begin{array}{l}-1.38 \\
(0.17)\end{array}$ \\
\hline \multirow[t]{2}{*}{ Bangladesh } & 1996 & $\begin{array}{c}-0.41 \\
(0.34)\end{array}$ & $\begin{array}{l}-0.57 \\
(0.24)\end{array}$ & $\begin{array}{l}-0.53 \\
(0.27)\end{array}$ & $\begin{array}{l}-0.65 \\
(0.18)\end{array}$ & $\begin{array}{l}-0.43 \\
(0.24)\end{array}$ & $\begin{array}{l}-0.31 \\
(0.21)\end{array}$ \\
\hline & 2002 & $\begin{array}{c}-0.61 \\
(0.22)\end{array}$ & $\begin{array}{c}-0.53 \\
(0.16)\end{array}$ & $\begin{array}{c}-1.05 \\
(0.18)\end{array}$ & $\begin{array}{c}-0.78 \\
(0.14)\end{array}$ & $\begin{array}{c}-1.12 \\
(0.16)\end{array}$ & $\begin{array}{l}-0.57 \\
(0.17)\end{array}$ \\
\hline \multirow[t]{2}{*}{ India } & 1996 & $\begin{array}{c}-0.55 \\
(0.27)\end{array}$ & $\begin{array}{l}-0.16 \\
(0.20)\end{array}$ & $\begin{array}{l}-0.13 \\
(0.21)\end{array}$ & $\begin{array}{l}-0.01 \\
(0.15)\end{array}$ & $\begin{array}{l}-0.29 \\
(0.17)\end{array}$ & $\begin{array}{c}0.27 \\
(0.21)\end{array}$ \\
\hline & 2002 & $\begin{array}{c}-0.84 \\
(0.20)\end{array}$ & $\begin{array}{c}-0.13 \\
(0.15)\end{array}$ & $\begin{array}{c}-0.34 \\
(0.17)\end{array}$ & $\begin{array}{c}0.07 \\
(0.13)\end{array}$ & $\begin{array}{c}-0.25 \\
(0.15)\end{array}$ & $\begin{array}{c}0.38 \\
(0.17)\end{array}$ \\
\hline \multirow[t]{2}{*}{ Nepal } & 1996 & $\begin{array}{c}0.14 \\
(0.65)\end{array}$ & $\begin{array}{l}-0.32 \\
(0.41)\end{array}$ & $\begin{array}{l}-0.24 \\
(0.43)\end{array}$ & $\begin{array}{l}-0.34 \\
(0.32)\end{array}$ & $\begin{array}{l}-0.26 \\
(0.47)\end{array}$ & $\begin{array}{c}0.13 \\
(0.35)\end{array}$ \\
\hline & 2002 & $\begin{array}{l}-1.63 \\
(0.34)\end{array}$ & $\begin{array}{c}-0.51 \\
(0.26)\end{array}$ & $\begin{array}{l}-0.41 \\
(0.19)\end{array}$ & $\begin{array}{c}-0.50 \\
(0.20)\end{array}$ & $\begin{array}{c}-0.30 \\
(0.22)\end{array}$ & $\begin{array}{c}-0.52 \\
(0.23)\end{array}$ \\
\hline \multirow[t]{2}{*}{ Pakistan } & 1996 & $\begin{array}{l}-1.01 \\
(0.29)\end{array}$ & $\begin{array}{l}-0.39 \\
(0.22)\end{array}$ & $\begin{array}{l}-0.56 \\
(0.27)\end{array}$ & $\begin{array}{l}-0.41 \\
(0.17)\end{array}$ & $\begin{array}{l}-0.91 \\
(0.23)\end{array}$ & $\begin{array}{l}-0.93 \\
(0.21)\end{array}$ \\
\hline & 2002 & $\begin{array}{l}-1.26 \\
(0.22)\end{array}$ & $\begin{array}{c}-0.50 \\
(0.17)\end{array}$ & $\begin{array}{l}-0.77 \\
(0.19)\end{array}$ & $\begin{array}{l}-0.70 \\
(0.14)\end{array}$ & $\begin{array}{c}-0.73 \\
(0.17)\end{array}$ & $\begin{array}{l}-1.10 \\
(0.18)\end{array}$ \\
\hline \multirow[t]{2}{*}{ Sri Lanka } & 1996 & $\begin{array}{l}-1.51 \\
(0.34)\end{array}$ & $\begin{array}{l}-0.30 \\
(0.24)\end{array}$ & $\begin{array}{c}0.24 \\
(0.27)\end{array}$ & $\begin{array}{c}0.27 \\
(0.18)\end{array}$ & $\begin{array}{l}-0.21 \\
(0.24)\end{array}$ & $\begin{array}{l}-0.19 \\
(0.21)\end{array}$ \\
\hline & 2002 & $\begin{array}{c}-1.94 \\
(0.22)\end{array}$ & $\begin{array}{c}0.03 \\
(0.16)\end{array}$ & $\begin{array}{c}0.12 \\
(0.18)\end{array}$ & $\begin{array}{c}0.23 \\
(0.14)\end{array}$ & $\begin{array}{c}-0.14 \\
(0.16)\end{array}$ & $\begin{array}{l}-0.06 \\
(0.17)\end{array}$ \\
\hline
\end{tabular}

Source: Governance Matters III: Governance Indicators for 1996-2002, by Daniel Kaufmann, Aart Kraay and Massimo Mastruzzi, The World Bank, June 30, 2003, based on poll and survey data from 18

organizations and 25 sources. The six cluster indices are constructed from 250 individual measures. 